\title{
Integrating Academic Journal Review Assignments Into A Graduate Business Leadership Course
}

Jennifer L. Schultz, Metropolitan State University, USA

Lisa M. Agrimonti, Fredrikson \& Byron, USA

Jeanne L. Higbee, University of Minnesota, USA

\begin{abstract}
Graduate course assignments that are pragmatic, challenging, scaffold prior learning, and support academic career aspirations can be difficult to create and even more problematic to assess for even the most experienced faculty. This paper presents a class assignment that incorporated a real-world journal reviewing assignment into an elective doctoral leadership seminar. This manuscript presents an overview of the assignment, journal editor perceptions of the experience, and recommendations for best practices.
\end{abstract}

Keywords: Graduate Student Professional Development; Management Education; Critical Review Mentoring

\section{INTRODUCTION}

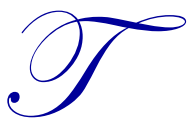

he increase in professional doctoral programs in schools of management has created new expectations for university faculty in preparing students for careers in academe, specifically in the areas of academic writing and publication. Training pragmatic researchers capable of solving the big, messy wicked problems of business and communicating their innovations through scholarly dissemination requires faculty to teach, mentor and support students in new and innovative ways. This manuscript will present (a) the evolving context of professional doctoral programs, (b) the rationale for supporting student peer reviews, (c) faculty and peer mentoring approaches to peer review, and (d) a pilot project initiative intended to develop doctoral student peerreviewing skills.

\section{Professional Doctoral Programs}

The development and growth of doctoral programs has historically been rooted in professional orientations (Kot \& Hendel, 2012). Recent trends in management education have seen increasing numbers of practitioner doctorates, which are also referred to as professional doctorates, applied doctorates, or clinical doctorates. In business, these degrees lead to the Doctor of Business Administration (DBA), Doctorate in Management for Professionals (DMP) or PhD in Management for Professionals. These are doctorates, most often post-MBA programs, not to be confused with the British DBA, Diploma of Business Administration, or DMS, Diploma in Management Studies, designations (Gump, 2005).

Where the PhD aims to develop professional researchers, the DBA is designed to develop researching professionals (Bourner, Bowden, \& Laing, 2001) with an intention of contributing new knowledge to both theory and practice (Lockhart \& Stablein, 2002). At the individual level, applied doctorates aim to provide research-oriented career development for experienced senior and executive professionals (Bareham, Bourner, \& Ruggeri Stevens, 2000). However, at the institutional level, the programs are seen as a way to increase prestige for the institution and as a mechanism to diversify doctoral degree recipients (Caldwell, White, \& Red Owl, 2007). Professionally, these programs are intended to employ reflective practice as the framework to bridge the gap between industry and academe (Banerjee \& Morley, 2013). 
According to Bareham, Bourner, Ruggeri Stevens and (2000), there is reasonable consensus that the applied doctorate in business is a research-based program that is aimed at developing the students' capacity to apply theory and research to management practice (p. 15). The capstone research project results in organizational change and provides a significant original contribution to the field (Lester, 2004). DBA programs are often completed part-time by full-time senior managers or executives, using a cohort or communities of learner's model to support scholarpractitioner development (Fenge, 2009).

There is a natural tension between creation of new knowledge (theory and research) and learning outcomes at the graduate student level (Boud \& Lee, 2005) that supports practitioner-scholar development. Creating opportunities and a variety of ways for students to develop and demonstrate their learning in the classroom can help bridge the theory-to-practice gap.

\section{Doctoral Student Publishing}

Publishing rates for dissertations and during doctoral study are low (Lee \& Kamler, 2008). Current models of student support for publication are scant, intermittent, improvised or absent (Lee \& Kamler, 2008; Maher, Timmerman, Feldon, \& Strickland, 2013), yet students supported by faculty or at institutions with a clear postgraduate publication policy have higher publication rates (Dinham \& Scott, 2001). Doctoral programs need to provide strategical support for a more inclusive orientation towards peer-reviewed publication.

That said, strategies such as offering courses to mentor writing for publication (Jalongo, Boyer, \& Ebbeck, 2014; Mandell, Shalan, Stalker, \& Caragata, 2015), beginning scholarly publication instruction early (Mizzi, 2014) and sustaining it throughout the academic program, introducing class assignments that align with publication expectations, providing opportunities for peer and instructor review of assignments (Belcher, 2009), writing retreats (Singh, 2012) and writing circles (Lassigm Dillon, \& Diezmann, 2013; Plakhotnik \& Rocco, 2012) will all promote student writing for academic publication. According to Lovitts (2008), doctoral students who publish their work have improved graduation rates and exhibit attributes that help them professionally. These attributes include (a) analytical, practical, and creative intelligence; (b) formal and informal ways of knowing; and (c), intrinsic and extrinsic motivation. Writing for publication needs to be embedded and supported in doctoral curricula (Lee \& Kamler, 2008).

\section{Development of Student Proficiency}

In some ways, faculty are providing realistic job previews to graduate students when they design opportunities for students to take on pragmatic academic assignments. This approach provides a platform for developing the skills needed to be successful in the academic environment (Lechuga, 2011). Peer review is an important tool for student writers (Chittum \& Bryant, 2014) that can connect them with a network that supports socialization in becoming a researcher (Lee \& Kamler, 2008). Creating environments that move students from being a student peer to research peer through peer reviewer opportunities in an area in which they are developing expertise helps build their selfefficacy as writers, scholars, and doctoral students.

Doctoral students often know little about the refereed publication process, yet getting published is a significant and important aspect to entering their professions (Cheung, 2010). Peer review can be an important aspect in furthering new knowledge; however doctoral students usually have little or no training in peer-review skills and limited or no experience as a reviewer (Lovejoy, Revenson, \& France, 2011). Yet research shows that peer mentoring in the form of peer review enhances writing skill development (Badger, 2010) and students can improve their own research and writing skills when (through peer review) they are able to identify good and possibly not so good academic work (McCutchen, 1991).

The research process should not be done in isolation (Lee \& Boud, 2003). It is clear that most doctoral students need help with academic writing (Collins, 2015; Nolan \& Rocco, 2009), developing conference proposals (Jalongo, 2013), writing collaboration, and critiquing peers (Cotterall, 2011). Learning from and with peers and participating in research discourse and publication practices are developmental practices in professional socialization for students 
(Boud \& Lee, 2005). Lee and Boud (2003) asserted that the development of research skills that lead to publication is rooted in writing support.

Writing groups have gained popularity and have been used successfully to assist both students and faculty in overcoming their fears and developing research and writing skills (Aitchison, 2009; Cuthbert \& Spark, 2008; Lee \& Boud, 2003; Maher, Seaton, McMullen, Fitzgerald, Otsuji, \& Lee, 2008). Research supports that writing groups can play a significant role in creating engaged student scholars (Lee \& Boud, 2003). In writing groups, where giving and receiving feedback is at the center of the pedagogical practice and learning to critique develops writing skills, the interaction and interrelation of members create the learning before, during, and after the writing happens (Aitchison, 2009). Peer review is an important aspect in specialization and the validation of new knowledge-an academic "trial by jury" (McCutchen, 1991, p. 28). Student peer review is another way to develop research skills and cross the divide from student to scholar and build an identity as an academic (Maher et al., 2008).

\section{Faculty and Mentoring}

Receiving mentoring in developing writing skills, mastering professional publication style guidelines, and preparing manuscripts (including those based on theses, capstone projects, and dissertations) is a high priority for many graduate students (Duranczyk, Franko, Osifuye, Barton, \& Higbee, 2015). Doctoral students are traditionally advised when working on dissertations, but more long-term mentoring initiatives from point of enrollment to degree completion and beyond can be a significant factor in improving outcomes related to expanded personal and professional networks, academic development, and creating a foundation for success in their profession (Holley \& Caldwell, 2012; Mizzi, 2014). Graduate students report that relationships (formal and informal) with faculty are significant and critical to their educational experiences, aiding in socialization to the professoriate. Meanwhile, faculty benefit from mentoring relationships through increased productivity (Lechuga, 2011).

Many faculties have networks to introduce students to professional organizations that could be venues for publication (Cheung, 2010), but mentoring students can often fall short due to faculty time and skill limitations (Moak \& Walker, 2014). Students report meaningful learning as a result of mentorship, yet faculty undervalue its significance (Linden, Ohlin, \& Broden, 2013). Mentoring can be particularly beneficial for professional and organizational socialization (Linden, Ohlin, \& Broden, 2013). Mentoring students in peer reviewing benefits the student and the profession.

\section{Peer Reviewing}

Reviewing can be an intellectually engaging task (Lovejoy, Revenson, \& France, 2011). Students are often underprepared for writing at the graduate level (Moak \& Walker, 2014) and need support throughout the publication process (including peer review) to improve their publication prospects (Cuthbert \& Spark, 2008). Reading journal articles is a good first step toward publication, providing an understanding of writing style, publication topics, and readership interests (Cheung, 2010). Interacting with authors and journal editors has legitimate rewards for learners (Doran, Somerville, Harlem-Siegel, \& Steele, 2014; McCutchen, 1991).

\section{Implementing a Peer-Review Assignment}

In summer 2014, students enrolled in DBA755: Topics in Business Leadership, a doctoral business administration seminar at a mid-sized public teaching university in the Midwestern region of the United States were assigned a selfdirected peer-review assignment as part of the class assessments. For the assignment, students had the opportunity to develop a peer-review project where they were asked to "REVIEW: Read, reflect, summarize, and/or analyze academic manuscripts. Develop critical thinking skills related to leadership and leadership development." Students were encouraged to review for professional conferences, books, journals, or select another peer-reviewing assignment that met their academic needs. Of these options, learning to critique a journal article can provide a much more sophisticated and comprehensive set of analytical and communication skills. Students chose the venue for their assignment and then had the opportunity to decide how much the assignment would be weighted in the calculation of their final course grade. As a precursor to the assignment, the faculty member required out-of-class reading and then covered the topic as part of a class lecture. 
Of the four students enrolled in the course, one student chose to complete the assignment by reviewing for an academic journal. The journal editor was asked to reflect on her experiences with the assignment and provide recommendations for faculty who might consider using this type of assignment in their own work.

\section{Course Context}

DBA755 is an elective offered in the third and final year of a 52-credit, post-MBA degree. The program is for experienced business professionals to prepare them for careers in business management, postsecondary teaching, and management consulting. The coursework and research project are intended to (a) support knowledge of management and research, (b) develop managerial skills, and (c) strengthen research and analytical skills.

\section{Course Details}

The course description for DBA755: Topics in Business Leadership provided in the course syllabus reads as follows:

This course is an integrated multi-disciplinary inquiry seminar of the critical problems facing the pragmatic and academic nature of leadership theory and practice. The broad scope of this course explores the impact of leadership theory, research and practice on individual, group, and organization outcomes. This course focuses on emerging and applied research and theory in leadership.

The course learning outcomes listed in the syllabus were:

- Understand the complex systems nature of leadership theory, research and practice. Be able to describe and evaluate the roles of theory, practice, and research in the leadership discipline.

- Gain a pragmatic understanding of the differing perspectives on leadership as a framework for further research. Evaluate and integrate the multiple ways of knowing.

- Identify and reflect on relevant gaps in academic and practical leadership research. Create an original work that may include a review, analysis, discussion or recommendations for further research.

- Read, reflect, summarize, and/or analyze academic manuscripts. Develop critical thinking skills related to leadership and leadership development.

Students were asked to read and be prepared to discuss Schwab (1985), Romanelli (1996), and Leblebici (1996) prior to the class period that covered peer-review skills and expectations. Class time was spent covering (a) what is reviewed, (b) why reviewing is needed in the academy, (c) personal developmental benefits to peer reviewing, (d) good and bad reviewing practices, and (e) evaluation criteria guidelines.

\section{Assignment Description}

The foundation for this course assignment is constructivist scholarship, where learning is considered an active process; knowledge is personal and is constructed, not discovered; and learners need meaningful, unrestricted, challenging and stimulating problems (Fox, 2001). The assignment leveraged the theoretical frames of Kolb (1984) through creating a new learning experience for students and an opportunity for reflective practice and application of this learning. Knowles' (1984) adult learning theory was also explicit in the assignment through problem-centered assignment design, relevance, and active student involvement in learning.

\section{First-Person Account Provided by the Journal Editor}

It can be difficult to identify strong reviewers who have extensive content knowledge, can determine the strengths and limitations of different research methods, understand statistical analyses, and are willing to commit the time to doing more than a cursory reading and provide feedback. From my own experience as a journal, book, and 
monograph series editor over the past 25 years, I am well aware that some faculty volunteer to serve on editorial boards in order to boost their curriculum vitae or pad the professional service section of their annual activity report, but fail to meet deadlines or never return the review at all or provide feedback that is neither correct nor helpful. Editors are sometimes placed in awkward positions because one reviewer will praise a manuscript and recommend to accept it while another adamantly votes to reject it. Often this discrepancy is due to the knowledge and time on task that each reviewer commits to the work. Thus, I was pleased to participate in this pilot project because there are few opportunities to mentor graduate students in the science and art of manuscript review. I fully recognize the benefits for editors and publishers as well as for the participating students.

For this pilot project the faculty member contacted me well in advance of the beginning of the semester to determine whether I was willing to serve as a mentor and provided a copy of the course syllabus. An additional factor that influenced my decision to participate was the required pre-reading for this assignment. I realized that any students involved would be well informed about professional practice and ethics. It is important to note that these students are involved in a post-master's program, and thus already have academic credentials that are comparable to those of some faculty and student development professionals who serve on editorial boards.

I also noted in the syllabus that the faculty member allowed a reasonable amount of time between deadlines so that the student would have the same amount of time to complete a meaningful review as the members of the editorial board. The Journal of College Teaching and Learning, published by The Clute Institute, allows 8 weeks from date of submission to provision of initial feedback to the author(s) for the editorial process. I generally ask that reviews be completed within 4 weeks of when I assign them and send them to the reviewers. In this case the faculty member serves on the journal's editorial board, and was thus already aware of the typical turn-around time expected. However, in most instances this would be the kind of information that the faculty member would want to ascertain from the editor prior to giving students the assignment. There needs to be ongoing communication between the faculty member and the journal editor.

The faculty member introduced me to the student via e-mail. From that point forward it was the student's responsibility to communicate with me directly. I considered that imperative. The faculty member and editor both need to be comfortable with the possibility that the student will not complete the assignment. For that reason I added the student as a third reviewer rather than in lieu of one of the two reviewers I would typically assign to the manuscript.

After the initial introductions, I asked the student about her areas of professional interest. This was an open-ended query, not a list of choices. I wanted to know how the student would describe her expertise. Upon receipt of the student's response, I provided the title of a possible manuscript for review in order to determine whether the student was comfortable with the specific topic. One advantage of using a publication like the Journal of College Teaching and Learning for this assignment is that at any given time there are likely to be papers submitted for review that do not require specific or extensive disciplinary content knowledge because the real focus of the paper is application of theoretical concepts to pedagogy and academic support. We receive submissions from faculty from a wide range of institutions, programs, and academic disciplines, but whether the topic is related to astronomy, engineering, education, leisure studies, business management, psychology, student services, and so on, it has some meaning for the general readership of the journal, and thus for the reviewers as well. 
I provided the student with the following guidelines for the review:

Attached is the article with the author's identifying information removed. I would appreciate it if you would provide responses to the following questions:

- Is the topic appropriate for the Journal of College Teaching and Learning? (Personal note: The scope of this journal is so broad that almost everything is.)

- Is the topic timely?

- Does the manuscript make a contribution to current knowledge and/or extend knowledge?

- Is the research methodology appropriate (if applicable)?

- Is the writing style clear and appropriate for a professional article?

- Do you have any recommendations to improve the manuscript?

- Would you recommend (a) accept, (b) accept pending minor revisions, (c) revise and resubmit, or (d) reject (and why if d)

I also welcome comments and/or tracked changes on the manuscript itself, but this is not necessary. You need not concern yourself with APA style issues - I take care of following up on those. (Personal communication, July 28,2014 )

The quality of the student's analysis and feedback for the author vastly exceeded my expectations. Her review was meaningful and thorough while also being concise. I quoted the student reviewer in my message to the author. I shared portions of that message with the student so that she would know that she had made a significant contribution to the review. It was not until this point that I realized that participating as a resource for assignments of this nature could provide a candidate pool for future reviewers, with foreknowledge of those who would be effective and reliable.

I realize that simulations could be provided for this assignment in lieu of a real-time review of a submitted manuscript, but I believe that true involvement in the review process provides a heightened source of motivation for the student participants and makes a contribution to the profession as well. On the other hand, I think that one way to enhance this assignment might be to provide a simulation assignment first and have students engage in smallgroup discussion of their reviews while also providing instructor feedback. It is unfortunate that editors seldom have the opportunity to provide similar professional development for editorial board members.

\section{DISCUSSION}

Creating assignments for graduate students that are interesting, pragmatic and rigorous is challenging. This pilot assignment was an attempt to do that for doctoral students in an elective business leadership course with success reported from the journal editor and student. That said, not all faculty make good mentors (Moak \& Walker, 2014) and business faculty in particular may not prove to be successful at mentoring students for publication. Schools of management house rather diverse academic disciplines (from finance and accounting to business law and technology) and at the graduate level often work with students outside of their areas of specialization. In addition, the diverse disciplines have significantly different publication venues and expectations. For example, accounting faculty often publish in professional trade journals while management faculty aim for peer-reviewed dissemination of their work in highly-ranked academic journals. The road to publication is very different across fields and can prove to be a barrier for faculty intending to support student publication aspirations. In addition, faculty who do not publish in peer-reviewed venues may be uncomfortable coordinating this type of class assignment. This is an area identified for further investigation.

Faculty demands, support and rewards can also hinder mentoring students for publication. Reviewing is expected of management scholars as service to their profession, yet it holds little reward in the tenure, promotion, and merit systems of our institutions. Good reviewing is important to maintain the quality of our journals, yet this can be an exhausting and time-consuming duty with strict and aggressive deadlines that do not always accommodate the reality of the faculty job responsibilities and academic calendars. The increasing pressure to teach more classes with 
larger enrollments and added administrative and service responsibilities at all levels compete for faculty time and create a paradigm for avoiding professional reviewing responsibilities.

Student interest and ability should be considered before embarking on this type of assignment. Some learners have no interest in peer reviewing. Career goals and intentions vary greatly at the graduate level, with many students in graduate management programs preparing for careers in consulting executive management roles where publication and peer-reviewing skills are not needed. Students who are interested in reviewing must understand best practices for reviewing and be willing to undertake this type of obligation because poor outcomes can negatively impact the student, faculty member, program reputation, and journal editor.

This assignment requires pre-planning and formalized relationships with journal editors, textbook companies, or professional conference track chairs. In order for this type of assignment to be successful, the faculty member must have existing relationships with professional associations, journal editors or other contacts for situations that require peer review. These relationships are difficult to form during the teaching term without previous contact and should be solidified before this type of task is expected from learners.

It is clear that faculty, editors and students benefit from journal peer reviewing, and reviewing is a natural developmental step to supporting publication. Additional investigation on ways to incorporate and encourage reviewing in graduate classrooms should be explored.

\section{CONCLUSION}

Peer-review learning assignments meet the increasing pressures on institutions to make their graduate and professional students visible, support student research for publication, assist students in understanding the audience for their work, build self-efficacy in research writing, and initiate an ethic of service to the profession. The challenge for faculty teaching in practitioner doctoral programs is to sustain relevance and engagement with practice while supporting traditional teaching and research models - all of which can be addressed in an academic journal peer-reviewing assignment. Students want real-world assignments and learning that are relevant and challenging. Peer reviewing helps students improve their own writing and research and can support publication skills. In short, the type of assignment outlined in this article can play an important role in promoting academic publication skills, expectations and outcomes for doctoral students.

\section{AUTHOR BIOGRAPHIES}

Jennifer L. Schultz is an Associate Professor in Human Resource Management (HRM) for The College of Management at Metropolitan State University in Minneapolis, Minnesota. She serves as the Curriculum Coordinator for the undergraduate HRM program and teaches graduate and undergraduate courses in leadership, management and HRM.

Lisa Agrimonti is a Shareholder in the Energy Division of Fredrikson \& Byron, P.A. where she specializes in public utility regulation, laws and property rights. She has been awarded Minnesota Super Lawyers Rising Star honor. She is a doctoral candidate at Metropolitan State University in Business Administration.

Jeanne L. Higbee recently retired from the Department of Postsecondary Teaching and Learning faculty in the College of Education and Human Development at the University of Minnesota, Twin Cities. Jeanne has served on a wide array of editorial boards and is currently the editor of The Clute Institute's Journal of College Teaching and Learning.

\section{REFERENCES}

Aitchison, C. (2009). Writing groups for doctoral education. Studies in Higher Education, 34, 905-916.

Badger, K. (2010). Peer teaching and review: A model for writing development and knowledge synthesis. Social Work Education, 29(1), 6-17. doi:10.1080/02615470902810850 
Banerjee, S., \& Morley, C. (2013). Professional doctorates in management: Toward a practice-based approach to doctoral education. Academy of Management Learning \& Education, 12(2), 173-193. doi:10.5465/amle.2012.0159

Bareham, J., Bourner, T., \& Ruggeri Stevens, G. (2000). The DBA: What is it for?' Career Development International, 5(7), 394403.

Belcher, W. L. (2009). Reflections on ten years of teaching writing for publication to graduate students and junior faculty. Journal of Scholarly Publishing, 40(2), 184-200. doi:10.3138/jsp.40.2.184

Boud, D., \& Lee, A. (2005). "Peer learning” as pedagogic discourse for research education. Studies in Higher Education, 30(5), 501-516. doi:10.1080/03075070500249138

Bourner, T., Bowden, R., \& Laing, S. (2001). Professional doctorates in England. Studies in Higher Education, 26(1), 65-83.

Bourner, T., Ruggeri Stevens, G., \& Bareham, J. (2000). The DBA: Form and unction. Education + Training, 42(9), $481-495$.

Caldwell, C., White, H., \& Red Owl, R. H. (2007). The case for creating a DBA program - A virtue-based opportunity for universities. Journal of Academic Ethics, 5(2/4), 179-188. doi:10.1007/s10805-007-9030-Z

Cheung, Y. L. (2010). First publications in refereed English journals: Difficulties, coping strategies, and recommendations for student training. Systems, 38, 134-141.

Chittum, J. R., \& Bryant, L. H. (2014). Reviewing to learn: Graduate student participation in the professional peer-review process to improve academic writing skills. International Journal of Teaching and Learning in Higher Education, 26(3), 473484.

Collins, J. C. (2015). Writing for publication while in graduate school: An accessible reality. New Horizons in Adult Education \& Human Resource Development, 27(1), 51-55. doi:10.1002/nha3.20094

Cotterall, S. (2011). Doctoral students' writing: Where's the pedagogy? Teaching in Higher Education, 16(4), 413-425. doi:10.1080/13562517.2011.560381

Cuthbert, D., \& Spark, C. (2008). Getting a GRiP: Examining the outcomes of a pilot program to support graduate research students in writing for publication. Studies in Higher Education, 33(1), 77-88.

Dinham, S., \& Scott, C. (2001). The experience of disseminating results of doctoral research. Journal of Further and Higher Education, 24(1), 45-55.

Doran, J. M., Somerville, W., Harlem-Siegel, J., \& Steele, H. (2014). The more you know: The impact of publication and peerreview experience on psychology graduate students. Teaching of Psychology, 41(2), 122-129.

Duranczyk, I. M., Franko, J., Osifuye, S., Barton, A., \& Higbee, J. L. (2015). Creating a model for graduate student inclusion and success. Critical Issues in Education Research, 8(3), 147-157.

Fenge, L. A. (2009). Professional doctorates-A better route for researching professionals? Social Work in Education, $28,165-$ 176.

Fox, R. (2001). Constructivism examined. Oxford Review of Education, 27(1), 23-35. doi:10.1080/3054980020030583

Gump, S. E. (2005). Examining the other DBA: The role of diploma programs in graduate business education in the United Kingdom. International Education, 34(2), 5-16.

Holley, K. A., \& Caldwell, M. L. (2012). The challenges of designing and implementing a doctoral student mentoring program. Innovative Higher Education, 37(3), 243-253.

Jalongo, M. (2013). Getting on the conference program and writing a practical article: Templates for success. Early Childhood Education Journal, 41(1), 13-23. doi:10.1007/s10643-012-0533-x

Jalongo, M. R., Boyer, W., \& Ebbeck, M. (2014). Writing for scholarly publication as "tacit knowledge": A qualitative focus group study of doctoral students in education. Early Childhood Education Journal, 42, 241-250. doi:10.1007/s10643013-0624-3

Knowles, M. (1984). Andragogy in action. San Francisco, CA: Jossey-Bass.

Kolb, D. A. (1984). Experiential learning: Experience as the source of learning and development. Englewood Cliffs, NJ: Prentice-Hall.

Kot, F. C., \& Hendel, D. D. (2012). Emergence and growth of professional doctorates in the United States, United Kingdom, Canada and Australia: A comparative analysis. Studies in Higher Education, 37(3), 345-364.

Lassig, C. J., Dillon, L. H., \& Diezmann, C. M. (2013). Student or scholar? Transforming identities through a research writing group. Studies in Continuing Education, 35(3), 299-314.

Leblebici, H. (1996). The act of reviewing and becoming a reviewer. In P. J. Frost \& M. S. Taylor (Eds.), Rhythms of academic life: Personal accounts of careers in academia (pp. 269-273). Thousand Oaks, CA: Sage.

Lechuga, V. M. (2011). Faculty-graduate student mentoring relationships: Mentors' perceived roles and responsibilities. Higher Education: The International Journal of Higher Education and Educational Planning, 62(6), 757-771.

Lee, A., \& Boud, D. (2003). Writing groups, change and academic identity: Research development as local practice. Studies in Higher Education, 28(2), 187.

Lee, A., \& Kamler, B. (2008). Bringing pedagogy to doctoral publishing. Teaching in Higher Education, 13(5), 511-523. doi:10.1080/13562510802334723

Lester, S. (2004). Conceptualizing the practitioner doctorate. Studies in Higher Education, 29, 757-770.

Linden, J., Ohlin, M., \& Brodin, E. M. (2013). Mentorship, supervision and learning experience in PhD education. Studies in Higher Education, 38(5), 639-662. 
Lockhart, J. C., \& Stablein, R. E. (2002). Spanning the academy-Practice divide with doctoral education in business. Higher Education Research \& Development, 21(2), 191-202. doi:10.1080/07294360220144105

Lovejoy, T. I., Revenson, T. A., \& France, C. R. (2011). Reviewing manuscripts for peer-review journals: A primer for novice and seasoned reviewers. Annals of Behavioral Medicine, 42(1), 1-13. doi:10.1007/s12160-011-9269-x

Lovitts, B. E. (2008). The transition to independent research: Who makes it, who doesn't, and why. Journal of Higher Education, 79, 296-325.

Maher, D., Seaton, L., McMullen, C., Fitzgerald, T., Otsuji, E., \& Lee, A. (2008). "Becoming and being writers": The experiences of doctoral students in writing groups. Studies in Continuing Education, 30(3), 263-275. doi:10.1080/01580370802439870

Maher, M. A., Timmerman, B. C., Feldon, D. F., \& Strickland, D. (2013). Factors affecting the occurrence of faculty-doctoral student coauthorship. Journal of Higher Education, 84(1), 121-143.

Mandell, D., Shalan, H., Stalker, C., \& Caragata, L. (2015). Writing for publication: Assessment of a course for social work doctoral students. Journal of Teaching in Social Work, 35(1-2), 197-212.

McCutchen, C. (1991). Peer review: Treacherous servant, disastrous master. Technology Review, 94(7), 28-38.

Moak, S. C., \& Walker, J. T. (2014). How to be a successful mentor. Journal of Contemporary Criminal Justice, 30(4), 427-442. doi:10.1177/1043986214541608

Mizzi, R. C. (2014). Writing realities: An exploration of drawbacks and benefits of publishing while enrolled in a doctoral program. New Horizons in Adult Education \& Human Resource Development, 26(2), 54-59.

Nolan, R., \& Rocco, T. (2009). Teaching graduate students in the social sciences writing for publication. International Journal of Teaching and Learning in Higher Education, 20(2), 267-273.

Plakhotnik, M. S., \& Rocco, T. S. (2012). Implementing writing support circles with adult learners in a nonformal education setting: Priority, practice, and process. Adult Learning, 23(2), 76-81. doi:10.1177/1045159512443507

Romanelli, E. (1996). Becoming a reviewer: Lessons somewhat painfully learned. In P. J. Frost \& M. S. Taylor (Eds.), Rhythms of academic life: Personal accounts of careers in academia (pp. 263-267). Thousand Oaks, CA: Sage.

Schwab, D. P. (1985). Reviewing empirically based manuscripts: Perspectives on process. Perspective on publishing. In L. L. Cummings \& P. J. Frost (Eds.), Publishing in the organizational sciences (pp. 171-181). Homewood, IL: Richard D. Irwin.

Singh, R. J. (2012). Promoting writing for research: The "writing retreat" model. South African Journal of Higher Education, $26(1), 66-76$. 
NOTES 